\title{
Bone Marrow-Derived Mononuclear Cell Therapy Accelerates Renal Ischemia- Reperfusion Injury Recovery by Modulating Inflammatory, Antioxidant and Apoptotic Related Molecules
}

\author{
Felipe Mateus Ornellas ${ }^{a, b}$ Débora Santos Ornellas ${ }^{a}$ Sabrina Vargas Martini ${ }^{a}$ \\ Raquel Carvalho Castiglione a,f Grasiella Maria Ventura ${ }^{d}$ Patrícia R. Roccoc \\ Bianca Gutfilen ${ }^{\mathrm{S}}$ Sergio A. de Souza ${ }^{\mathrm{e}}$ Christina Maeda Takiyab \\ Marcelo Marcos Morales ${ }^{a}$

\begin{abstract}
aLaboratory of Cellular and Molecular Physiology, 'baboratory of Immunopathology, 'Laboratory of Pulmonary Investigation, Institute of Biophysics Carlos Chagas Filho, dConfocal Microscopy Unit, Institute of Biomedical Science, e'Department of Radiology, School of Medicine, Federal University of Rio de Janeiro, Rio de Janeiro, fLaboratory for Clinical and Experimental Research on Vascular Biology, Biomedical Center, State University of Rio de Janeiro, Rio de Janeiro, Brazil
\end{abstract}

\section{Key Words}

Ischemia- reperfusion • Renal • Cellular therapy • Bone marrow

\begin{abstract}
Background/Aims: We investigated the regenerative capacity of intravenous administration of bone marrow-derived mononuclear cells (BMMCs) in a rat model of bilateral renal ischemia/reperfusion (IR) injury and the involvement of inflammatory, anti-inflammatory, and other biological markers in this process. Methods: Rats were subjected to $1 \mathrm{~h}$ bilateral renal pedicle clamping. BMMCs were injected i.v $1 \mathrm{~h}$ after reperfusion and tracked by ${ }^{99 \mathrm{~m} T \mathrm{~T}}$ and GFP+ BMMCs. Twenty-four hours after reperfusion, renal function and histological changes were evaluated. The mRNA (real time PCR) and protein (ELISA and immuno-staining) expression of biological markers were analyzed. Results: Renal function and structure improved after infusion of BMMCs in the IR group (IR-C). Labeled BMMCs were found in the kidneys after therapy. The expression of inflammatory and biological markers (TLR-2, TRL-4, RAGE, IL-17, HMGB-1, KIM-1) were reduced and the expression of anti-inflammatory and antioxidant markers (IL-10, Nrf2, and HO-1) were increased in IR-C animals compared with IR untreated animals (IR-S). The apoptotic index diminished and the proliferation index increased in IR-C compared with IR-S. Conclusion: The results contribute to our understanding of the role of different biological players in morphofunctional renal improvement and cytoprotection in a post-ischemic reperfusion kidney injury model subjected to cellular therapy.

\section{KARGER}




\section{Cellular Physiology Cell Physiol Biochem 2017;41:1736-1752 and Biochemistry Published online: March 31, $2017 \quad \begin{aligned} & \text { O 2017 The Authors. } \\ & \text { www.karger.com/cpb }\end{aligned}$

\section{Introduction}

Acute tubular necrosis (ATN) is the most common cause of acute renal failure in the hospital and in the intensive care unit; it occurs in $88 \%$ of all cases of acute kidney injury (AKI) and has high morbidity and mortality [1]. Ischemia/reperfusion injury (IRI) of renal allografts is also a form of ATN, and depending on its severity and duration results in nonfunctional grafts and delayed graft injury with long-term chronic renal ischemia and hypoxia [2].

IRI is a complex event that involves injury caused by the metabolic changes induced by the depletion of adenosine triphosphate (ATP) and by reactive oxygen species (ROS) formed after reperfusion. Both tubular epithelial cells and endothelial cells are affected and die by apoptosis, necrosis, and autophagy-associated cell death [3]. Necrotic cells allow the escape of intracellular molecules such as ATP and high-mobility group box-1 (HMGB1), molecules collectively called damage-associated molecular patterns (DAMPs), which bind to specific receptors leading to the recruitment and activation of innate immune system cells. Recent evidence shows the importance of these DAMPs in the induction and amplification of the inflammatory responses in vivo in the context of IRI and the reduction in the inflammatory response observed when they are inhibited [4].

Despite huge advances in knowledge on the pathophysiology of renal injury induced by IR, detection, prevention, and treatment are still limited [5]. AKI represents the final consequence of a series of biological processes elicited after the initial insult and subsequent host response. Repair mechanisms initiate the reparative response simultaneously with the injury, and if adequate tubular cell proliferation and resolution of inflammation occurs, the process is spontaneously resolved with a decrease in damage biomarkers and a rapid return of renal function. Normal repair involves a complex network of growth factors, and proliferative and other signaling cascades, which must operate in a coordinated way and be temporally and spatially integrated [6]. The repair process is carried out by viable tubular renal cells that become dedifferentiated, re-express developmental programs, and migrate to the sites of cell loss, where they engraft and redifferentiate to regain polarity and function $[7,8]$. These events are accompanied by downregulation of pro-inflammatory cytokines, diminution in adhesion molecules, and subsequent decrease in inflammation, with gradual improvement of renal blood flow and glomerular filtration rate (GFR), and return of tubular and vascular integrity and function [7]. However, when the injury is too severe, the regenerative capacity of the kidney is overwhelmed. To avoid the high morbidity and mortality seen in humans, alternative treatments have been proposed to halt and decrease tubular and endothelial damage, reduce inflammatory response, and stimulate repair [9]. AKI treatment remains largely supportive, including dialysis, fluid maintenance, and use of vasoactive drugs and cytoprotective therapy among others [2]. Therefore, there is an urgent need to develop innovative strategies focused on specific targets such as inflammation, and vascular, endothelial, and tubular regeneration. Therapeutic use of adult stem cells may be one of these innovative therapies.

Cell-based therapy is a promising strategy for several pathological conditions, including severe acute or chronic kidney disease and is currently the focus of preclinical studies. The beneficial regenerative effects of various (stem) cell populations and cell-derived factors (secreted growth factors, microvesicles, and exosomes) seen in animal models of AKI have been translated into clinical trials. The administration of allogeneic mesenchymal stromal cells (MSCs) to patients undergoing open-heart surgery who are at high risk of acute renal failure was proven to be feasible and safe [10]. Moreover, in kidney transplant recipients, stem cell therapy improved regeneration, decreased the incidence of acute rejection episodes, and led to a better estimated renal function at 6 months or 1 year [11].

Adult stem cells include bone marrow stem cells, comprising hematopoietic stem cells, and MSCs, endothelial progenitor cells, and organ specific stem cells. Although originally the beneficial effect of adult stem cells was thought to be through engraftment and regeneration [12], subsequent studies demonstrated that the main therapeutic effects were mediated primarily through the secretion of soluble factors. As cell-based therapies based on bone 


\section{Cellular Physiology Cell Physiol Biochem 2017;41:1736-1752 \begin{tabular}{c|l|l} 
DOI: 10.1159/000471866 & $\begin{array}{l}\text { ( ) } 2017 \text { The Author(s). Published by S. Karger AG, Basel } \\
\text { www.karger.com/cpb }\end{array}$
\end{tabular} \\ Ornellas et al.: BMMCs Role in Renal Ischemia and Reperfusion Injury}

marrow-derived mononuclear cells (BMMCs) were the first to be used, their effects, security, and failures are now widely known. Despite their promising results to improve structural recovery, complete functional improvement has still not been achieved [13-15]. Different from other types of cell therapies, therapy with BMMCs consists of a mixture of lymphoid, myeloid, erythroid, and stem cell populations, and specifically in humans, of T cells, B cells, monocytes, natural killer cells, and hematopoietic progenitor cells $[16,17]$. However, BMMCs have the advantage of easy isolation and separation of adequate amounts of BMMCs from a bone marrow aspiration, providing benefits similar to those obtained with MSCs $[18,19]$.

Therefore, due to the broader regenerative properties of BMMCs, we hypothesized that cellular therapy can help accelerate renal morphofunctional recovery in a model of bilateral ischemia/reperfusion-induced kidney injury by modulating key inflammatory, antioxidant, and apoptotic molecules.

\section{Materials and Methods}

\section{Animal Model}

All animal protocol studies were approved by the Ethics Committee of the Instituto de Biofísica Carlos Chagas Filho, Centro de Ciências da Saúde, Universidade Federal do Rio de Janeiro (Affidavit of Approval of Animal Use Protocol - IBCCF 168). Female 14- to 16-week-old Wistar rats were randomly assigned to one of five groups: control (CTRL), sham treated with saline (S-S), sham treated with BMMCs (S-C), ischemia and reperfusion treated with saline (IR-S), and ischemia and reperfusion treated with BMMC (IR-C). The animals that underwent IR injury were anesthetized with ketamine $(150 \mathrm{mg} / \mathrm{kg})$ and xylazine $(10 \mathrm{mg} /$ $\mathrm{kg}$ ) intraperitoneally, and injury was induced by clamping both renal pedicles for $1 \mathrm{~h}$ (bilaterally) with a microvascular non-traumatic clamp (Roca Instrumental, São Paulo, Brazil) through an abdominal incision. Sham animals were subjected to the same surgical procedure without clamping of the renal artery. Administration of BMMCs $\left(10^{6}\right)$ or sterile saline solution $(0.9 \% \mathrm{NaCl}, 0.15 \mathrm{~mL})$ was performed via the left jugular vein $1 \mathrm{~h}$ after reflow. Animals were monitored, and their temperature was maintained at $37^{\circ} \mathrm{C}$. Then animals were placed in a metabolic cage for $24 \mathrm{~h}$ before they were killed (Fig. 1).

Isolation and characterization of bone marrow-derived mononuclear cells from Wistar rats and transgenic GFP rats

BMMCs were harvested from the femur and tibia of 14- to 16-week-old male Wistar rats and transgenic Lewis rats (LEW-Tg (EGFP) F455.5/Rrrc) in which enhanced green fluorescent protein (EGFP) is expressed under the ubiquitin C promoter, kindly donated by Rosalia Mendez-Otero (Instituto de Biofísica Carlos Chagas Filho, Universidade Federal do Rio de Janeiro). Thereafter, BMMCs were injected as previously reported [15]. Bone marrow cells were aspirated by flushing the bone marrow cavity with Dulbecco's modified Eagle's medium (Life Technologies, Grand Island, NY). After reaching a homogeneous cell suspension, cells were centrifuged ( $400 \times g$ for $10 \mathrm{~min}$ ), re-suspended and added to Ficoll-Paque Plus

Fig. 1. Experimental design. A: Experimental groups: CTRL, control group; SHAM, faked surgical intervention; SAL, saline $(0,9 \% \mathrm{NaCl})$ group; IR, ischemia-reperfusion group; BMMC, bone marrow-derived mononuclear cells. (CTRL, control; S-S, sham + saline; S-C, BMMC; IR-S, ischemia/reperfusion + saline; IR-C, ischemia/reperfusion + BMMC). B: Timeline of the experimental protocol.

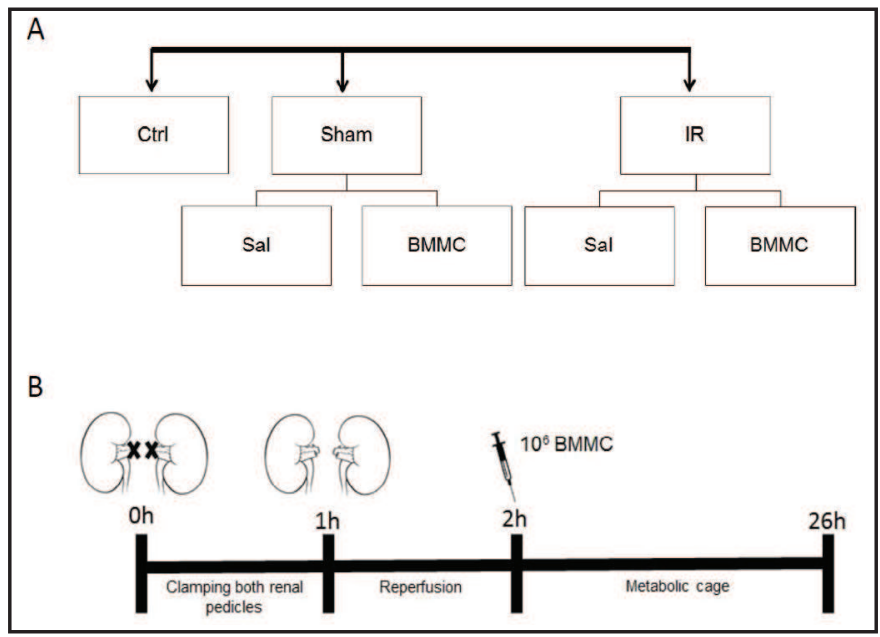




\section{Cellular Physiology Cell Physiol Biochem 2017;41:1736-1752 \begin{tabular}{l|l|l|l|l} 
and BOI: 10.1159/000471866 & (O) 2017 The Author(s). Published by S. Karger AG, Basel
\end{tabular}

(GE Healthcare Bio-Sciences AB, Uppsala, Sweden), and again centrifuged and re-suspended in phosphatebuffered saline. Cells were counted in a Neubauer chamber with trypan blue for evaluation of viability. The BMMC population from Wistar rats used in the experiments was previously characterized by flow cytometry as described by Castiglione et al. [15].

\section{Tracking of BMMCs}

Labeled with 99m-technetium. BMMCs were labeled with 99m-technetium ( ${ }^{99 \mathrm{~m}} \mathrm{Tc}$ ) according to protocols described previously [20]. Briefly, $500 \mathrm{~mL}$ of sterile $\mathrm{SnCl}_{2}$ solution was added to the cell suspension and the mixture was incubated at room temperature for $10 \mathrm{~min}$. Then, $5 \mathrm{mCi}$ of ${ }^{99 \mathrm{~m}} \mathrm{Tc}$ was added and incubated for more $10 \mathrm{~min}$. After centrifugation (5000 $\times \mathrm{g}$ for $5 \mathrm{~min}$ ), the supernatant was removed, and the cells were washed three times with $\mathrm{NaCl} 0.9 \%$. Viability of the labeled cells was assessed by the trypan blue exclusion test and was estimated to be greater than $93 \%$ in all cases. Labeling efficiency (\%) was calculated by the activity in the pellet divided by the sum of radioactivity in the pellet plus supernatant, and was estimated to be greater than $90 \%$ in all cases. $10^{6}{ }^{99 \mathrm{~m}} \mathrm{Tc}$-BMMCs were injected through the jugular vein immediately after labeling. Whole-body scintigraphy was performed on these animals for qualitative biodistribution in a dedicated small-animal Triumph II PET/SPECT/CT Imaging system (Gamma Medica-Ideas, Salem, NH) equipped with a high-resolution collimator and diagnostic computed tomography (CT) 2 and 4 h after ${ }^{99 \mathrm{~m} T c-}$ BMMC administration.

GFP+ BMMCs. Due to the short half-life of ${ }^{99 \mathrm{~m}} \mathrm{Tc}$, which only allows tracking of injected BMMCs up to the first hours after administration, we also used GFP+ BMMCs to localize them beyond $24 \mathrm{~h}$. Kidneys from animals injected with GFP+ BMMCs were harvested, longitudinally cut into 2 slices and frozen ( 3 animals per group). Frozen kidneys from both sides were sectioned with the cryostat (10- $\mu \mathrm{m}$ thick), and 100- $\mu \mathrm{m}$ thick sections were re-cut to obtain a total of 15 sections for each kidney slice (a total of 30 histological sections/animal). Sections were fixed with a $4 \%$ buffered paraformaldehyde solution (20 min), washed, and after permeabilization with PBS + 0.5\% Triton X-100 (Sigma-Aldrich, St Louis, MO), non-specific binding of immunoglobulins to tissue was blocked with PBS + 5\% bovine serum albumin (BSA) and 10\% normal goat serum (Sigma-Aldrich) for $1 \mathrm{~h}$. Then, a rabbit polyclonal antibody anti-GFP protein (Molecular Probes, Eugene, OR) was applied to the sections in a humid chamber for $16 \mathrm{~h}$ at $4^{\circ} \mathrm{C}$. Sections were then washed with $\mathrm{PBS}+0.25 \%$ Tween 20 solution and incubated with a goat anti-rabbit $\mathrm{F}\left(\mathrm{ab}^{\prime}\right)_{2}$ fragment of IgG conjugated to DyLight 488 (Jackson ImmunoResearch, West Grove, PA). Then, the sections were washed with PBS + Tween 20, stained with DAPI (4',6-diamidine-2'-phenylindole dihydrochloride; Santa Cruz Biotechnologies, Dallas, TX) for $5 \mathrm{~min}$, washed, and mounted with Vectashield (Vector Laboratories, Burlingame, CA). Photomicrographs of stained sections were obtained in an epifluorescence microscope (Nikon Eclipse E-800) and in a confocal microscope (Leica TCS SP5).

\section{Renal function}

To analyze renal function, all animals were placed in individual metabolic cages for $19 \mathrm{~h}$ with free access to water and food, and the last $5 \mathrm{~h}$ under fasting conditions but with free access to water. Urinary flow $(\mu \mathrm{L} / \mathrm{min}$ ) was determined from the urinary volume (collected in a 24 -h period in a metabolic cage) per time unit of urine collection. Urine was used to determine the following solutes: creatinine, sodium, and potassium.

Plasma and urinary creatinine concentrations were determined by a colorimetric method using picric acid (Gold Analisa Diagnóstica, São Paulo, Brazil). The results obtained from plasma and 24-h urine samples were used to calculate creatinine clearance $(\mu \mathrm{L} / \mathrm{min}$ ) using the following equation: (urinary flow $\times$ urinary creatinine concentration)/plasma creatinine concentration).

The GFR was determined using creatinine clearance normalized by corporal surface area $\left(\mu \mathrm{L} / \mathrm{min}\right.$ per $\left.\mathrm{cm}^{2}\right)$.

The concentrations of sodium and potassium were determined in plasma and urine using commercial kits following the manufacturer's instructions (HUMAN Diagnostic Worldwide, Wiesbaden, Germany). The results obtained from plasma and urine were used to calculate the clearance of sodium and potassium $(\mathrm{mL} / \mathrm{min})$ using the following equation: (urinary flow $\times$ urinary solute concentration)/plasma solute concentration. The following formula was used to determine the fraction of sodium and potassium excreted $\left(\mathrm{FE}^{-\mathrm{Na}^{+}}\right.$in $\%$ and $\mathrm{FE}-\mathrm{K}^{+}$in $\%$ ) was used (sodium or potassium clearance/creatinine clearance) $\times 100$. 


\section{Cellular Physiology Cell Physiol Biochem 2017;41:1736-1752 \begin{tabular}{c|c|c|c|} 
DOI: 10.1159/000471866 & () 2017 The Author(s). Published by S. Karger AG, Basel
\end{tabular} and Biochemistry Published online: March 31, 2017 www.karger.com/cpb}

Ornellas et al.: BMMCs Role in Renal Ischemia and Reperfusion Injury

Real-time quantitative PCR Table 1. Primer Sequences

\begin{tabular}{|c|c|c|c|}
\hline \multirow{3}{*}{$\begin{array}{c}\text { A quantitative real-time } \\
\text { reverse transcription }(\mathrm{RT}) \text { poly- }\end{array}$} & Gene & Sense & Anti-sense \\
\hline & GAPDH & $5^{\prime}$ GGTGAAGGTCGGTGTGAAC $3^{\prime}$ & $5^{\prime}$ CGTTGATGGCAACAATGTC $3^{\prime}$ \\
\hline & IL-10 & $5^{\prime}$ ' TCCCTGGGTGAGAAGCTG $3^{\prime}$ & 5' GCTCCACTGCCTTGCTCT 3' \\
\hline merase & IL-17 & $5^{\prime}$ TCTCCAGAACGTGAAGGTC $3^{\prime}$ & 5' AAGTGGAACGGTTGAGGTAG 3' \\
\hline measure & IL-18 & 5'ATATCGACCGAACAGCCAAC $3^{\prime}$ & 5' TAGGGTCACAGCCAGTCCTC $33^{\prime}$ \\
\hline vels of mRNA of tumor necrosis & KIM-1 & $5^{\prime}$ ATATCGACCGAAAGCCACA $3^{\prime}$ & $5^{\prime}$ TAGGGTCACAGCCAGTCCTC $3^{\prime}$ \\
\hline & Pro-caspase-3 & 5' GGCCGAATTAATGTATGC $3^{\prime}$ & 5' GCGCAAAGTGACTGGATG 3' \\
\hline & RAGE & $5^{\prime}$ TGAACTCACAGCCAATGTCC $3^{\prime}$ & $5^{\prime}$ ACAACTGTCCCTTTGCCATC $3^{\prime}$ \\
\hline , IL-17, IL-18, pro-caspase-3, & TLR-2 & $5^{\prime}$ ATGGGCTGTGGTATCTGAGAA $3^{\prime}$ & 5' AAACAAAGGCATAGCAAAGG $3^{\prime}$ \\
\hline tor for advanced glycation end & TRL-4 & 5' CGGAAAGTTATTGTGGTGT 3' & 5' GGACAATGAAGATGATGCCAGA $3^{\prime}$ \\
\hline ducts (RAGE) kidney ini & TNF- $\alpha$ & $5^{\prime}$ CCCAGACCCTCACACTCAG $3^{\prime}$ & 5' CTCTGCTTGGTGGTTTGCT $3^{\prime}$ \\
\hline
\end{tabular}
molecule-1 (KIM-1), toll-like receptor (TLR)-2, and TLR-4. Left kidneys were cut transversally in slices, collected in cryotubes, quick frozen by immersion in liquid nitrogen, and stored at $-80^{\circ} \mathrm{C}$. Total RNA was extracted with an RNeasy kit (QIAGEN, Valencia, CA), including a DNase-digestion step to exclude DNA contamination. RNA concentration was measured by spectrophotometry in Nanodrop ND-2000. First-strand cDNA was synthesized from total RNA using a QuantiTect Reverse Transcription Kit (QIAGEN). Real-time PCR primers for the target gene were purchased from Invitrogen (Carlsbad, CA). Relative mRNA levels were measured with BRYT Green system (Promega, Fitchburg, WI) using PCR Mastercycler ep Realplex Eppendorf (Eppendorf, Hamburg, Germany). All experiments were performed in triplicate. The relative expression of each gene was calculated as a ratio of the gene under study to the control gene, glyceraldehyde-3-phosphate dehydrogenase (GAPDH), and expressed as fold change relative to control $\left(2^{-\Delta \Delta C t}\right)$. The PCR primers used are listed in Table 1.

\section{Protein extraction and ELISA}

The renal tissue was homogenized in lysis buffer (250 mM sucrose, 20 mM HEPES, 1 mM EDTA, 50 $\mathrm{mM} \mathrm{NaF}, 1 \mathrm{mM}$ phenylmethylsulfonyl fluoride, 1× Roche protease inhibitor cocktail (Roche Diagnostic, Mannheim, Germany). After homogenization, the tissue homogenate was centrifuged at $600 \times g$ for 5 min, and the supernatant was transferred to a new tube and centrifuged again at $3000 \times g$ for 10 min. Protein concentration was quantified by the Bradford assay using BSA as the standard [21]. The total content of IL10 (BD Bioscience, Franklin Lakes, NJ) and KIM-1 (R\&D Systems, Minneapolis, MN) proteins in the kidney was quantified using specific ELISA kits.

\section{Histological score for tubular injury}

The kidneys were fixed, dehydrated, and embedded in paraffin. Slices (7- $\mu \mathrm{m}$ thick) were stained with periodic acid-Schiff and observed under a light microscope. Images from 30 to 35 fields from each group were captured randomly, and an average of 20 tubules were analyzed for tubular dilatation, apical cytoplasm vacuolization, cell detachment, brush border integrity, and denuded basement membrane and tubular necrosis, which characterizes proximal tubular injury. A lesion score was assigned in a blinded manner by a single observer (H.J.V.B.) using a 5-point scale [22] as follows: 1, without alterations; 2, mild alterations affecting $10 \%$ of tubules or fewer; 3 , alterations affecting $25 \%$ of tubules; 4 , alterations affecting $50 \%$ of tubules; and 5 , alterations in $75 \%$ or more tubules.

\section{Immunohistochemistry}

Immunohistochemical procedures were performed on 4- $\mu$ m-thick, paraffin-embedded kidney sections using the following antibodies: a mouse monoclonal antibody against rat CD68 to detect macrophages (AbDSerotec, Raleigh, NC); a mouse monoclonal antibody against proliferating cell nuclear antigen (PCNA) (DakoCytomation, Carpinteria, CA), a mouse monoclonal antibody to rat KIM-1 (R\&D Systems), Nfr-2, heme-oxigenase-1, and HMGB1 (AbCam, Cambridge, MA). After dewaxing and rehydrating, sections were submitted to endogenous peroxidase inhibition (15 min with $3 \% \mathrm{H}_{2} \mathrm{O}_{2}$ in methanol). Heat-mediated antigen retrieval and enzymatic techniques were performed according to the specific antibody. After blocking the non-specific binding of immunoglobulins to the tissue, primary antibodies were then incubated overnight at $4^{\circ} \mathrm{C}$ in a humidified chamber for about $16 \mathrm{~h}$. The sections were then washed in $0.25 \%$ Tween-PBS solution for $5 \mathrm{~min}$, and the secondary antibodies labeled with peroxidase Histofine MAX PO and anti-mouse or rabbit, both for rat tissue, were incubated (Nichirei Biosciences, Tokyo, Japan). The chromogen substrate was diaminobenzidine liquid (DakoCytomation). Negative control slides were incubated with mouse or rabbit isotype immunoglobulins or with the antibody diluent solution. 


\section{Cellular Physiology Cell Physiol Biochem 2017;41:1736-1752

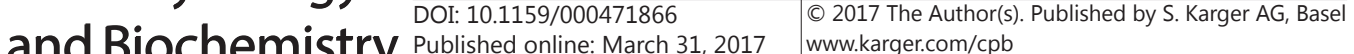 \\ Ornellas et al.: BMMCs Role in Renal Ischemia and Reperfusion Injury}

\section{Histomorphometry}

We used one slide/animal $(n=8)$, which contained two sections. For each section, 30 histological fields were analyzed for each group/marker. For histomorphometry, we used an image analysis system consisting of a light microscope (Eclipse E800; Nikon, Tokyo, Japan) coupled to a digital camera (Evolution; Media Cybernetics, Rockville, MD) with Q-Capture 2.95.0 graphic interface software (Quantitative Imaging, Surrey, BC, Canada). High-quality images (2048 × 1536-pixel buffer) were captured, and after calibration of the program settings, images were analyzed using Image Pro Plus software (version 4.5.1; Media Cybernetics). The brightness and contrast of the images were adjusted after the quantification to obtain better representation.

\section{F-actin network}

To visualize the filamentous actin (F-actin) network, frozen kidney sections (10- $\mu$ m thick) were obtained similarly to those for tracking GFP-BMMCs and placed on slides coated with poly-L-lysine and fixed with 4\% paraformaldehyde in PBS (pH 7.2) according to the technique described previously [23]. These sections were washed with PBS, permeabilized with PBS $+0.5 \%$ Triton X-100 ( 2 baths of 15 min), and incubated with phalloidin conjugated to Alexa 488 (Molecular Probes) for 20 min. After washing with PBS, sections were incubated with DAPI for $5 \mathrm{~min}$, washed, and mounted with Vectashield (Vector Laboratories).

\section{Statistical Analysis}

Data were analyzed using GraphPad Prism 5 (GraphPad Software, La Jolla, CA). Selection of the appropriate statistical tests was based variance and the underlying distribution of the data. Global effects between groups were first assessed using one-way analyses of variance with Bonferroni's correction for multiple comparisons, and results are expressed as means \pm SEM, with $P<0.05$ considered significant.

\section{Results}

BMMCs infusion attenuated IRI histological injury and renal function

IRI promote morphological alterations and diminution of the capacity of the renal tissue to maintain homeostasis [9]. IRI-induced histological injury was evaluated by a histological injury score as well as by evaluation of the actin filaments. Figure 2 shows representative cortical images of the histological parameters used to quantify injury: tubular dilatation, cell detachment, brush border integrity, denuded basement membrane, and tubular necrosis in the CTRL, S-S, S-C, IR-S, and IR-C groups. After BMMC infusion, renal tubules showed a quite preserved aspect with disappearance of denuded tubules, cell necrosis, or detachment. Brush borders depicted by PAS staining confirmed the maintenance of the tubular structure.

The F-actin network depicted by phalloidin-488 staining in the CTRL group animals showed preservation of actin microfilaments in renal tubules and glomeruli. After $24 \mathrm{~h}$ of IRI, tubular phalloidin-488 staining became intensely reduced or disrupted in the IR-S group. However, in the IR-C group, renal tubules presented a phalloidin network almost similar to that seen in the CTRL group. This shows that the tubular cells maintained their cytoskeletal microfilaments in the IR-C group compared with the IR-S group because of the attenuation of IRI in these animals (Fig. 3).

Moreover, renal function parameters such as urinary flow and GFR of the IR-C group were similar to those seen in the CTRL, S-S, and S-C groups $(P>0.05)$. However, the IR-S group showed a 0.60 - and 0.79-fold decrease in urinary flow and GFR (Table 2).

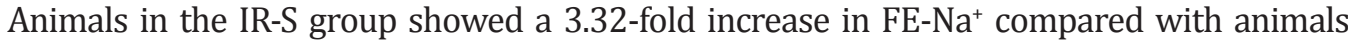
in the control groups (CTRL, S-S, and S-C), however, the animals in the IR-C group showed no significant difference in FE-Na ${ }^{+}$compared with animals in the CTRL, S-S, and S-C groups $(P>0.05)$. Animals in the IR-S group had a 4.25 -fold increase in FE- $\mathrm{K}^{+}$compared with animals in the control groups (CTRL, S-S, and, S-C). FE- $\mathrm{K}^{+}$decreased 0.26-fold in the IR-C group versus the IR-S group, which was not enough to reach the control levels (CTRL, S-S, and S-C) (Table 2).

Kidney injury molecule-1 is a biomarker of renal tubular injury

Tubular cell damage induced by IR can be detected early through analyses of the renal injury biomarker KIM-1 [24]. Figure 4A shows the localization of KIM-1 in renal tissue. 


\section{Cellular Physiology Cell Physiol Biochem 2017;41:1736-1752 \begin{tabular}{l|l|l} 
aOI: 10.1159/000471866 & ( 2017 The Author(s). Published by S. Karger AG, Basel \\
and Biochemistry
\end{tabular}}

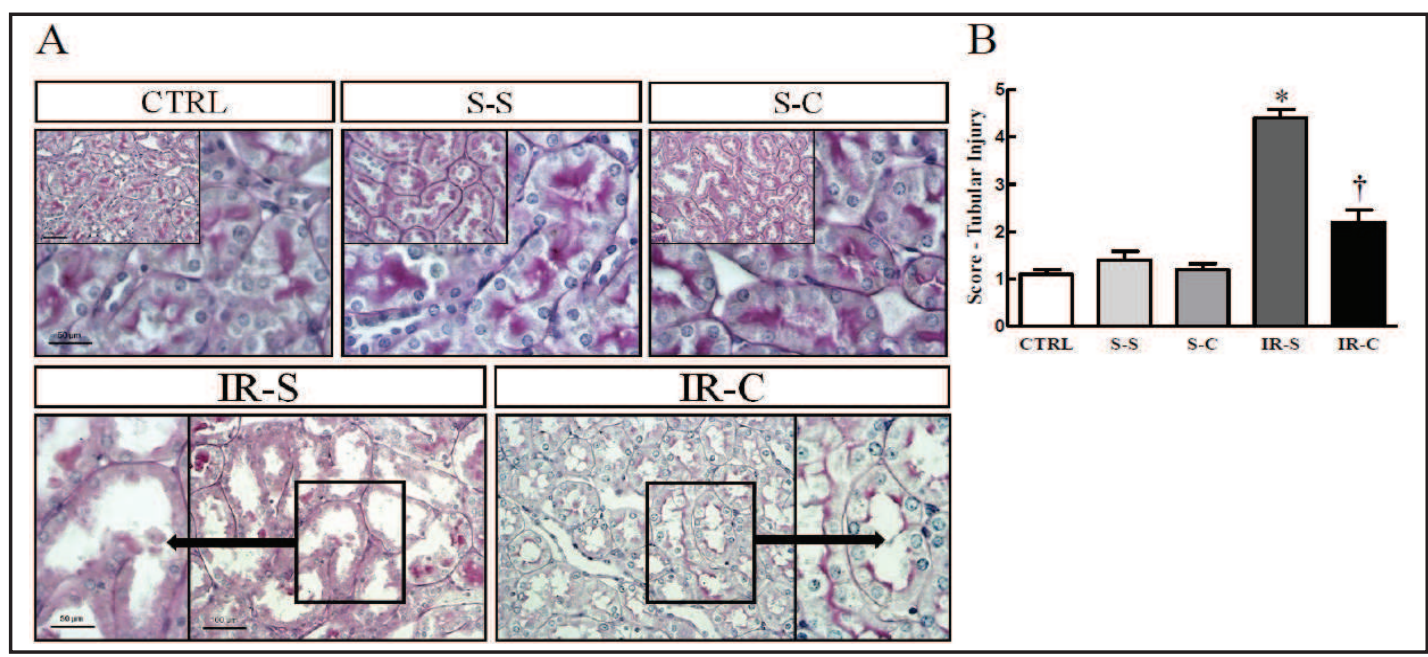

Fig. 2. Representative figure of the renal injury index in the cortical nephron. (A) Photomicrography of histologic slices of cortical nephron $(\times 200$ and $\times 400)$. (B) Graphic representation of the renal injury index: CTRL, control; S-S, sham + saline; S-C, BMMC; IR-S, ischemia/reperfusion + saline; IR-C, ischemia/reperfusion + BMMC. Data are expressed as means \pm standard error of the mean $(n=10)$. *Statistical significance of IR-S compared with all other groups $(P<0.05)$. $†$ Statistical significance of IR-C compared with CTRL, S-S, and S-C $(P<0.05)$.

Fig. 3. Immunofluorescence detection of phalloidin $(\times 400)$. CTRL, control; S-S, sham + saline; S-C, BMMC; IR-S, ischemia/reperfusion + saline; IR-C, ischemia/reperfusion + $\operatorname{BMMC}(n=4)$.

Immunoreactivity to KIM-1 was seen in injured tubules in IR-S, with diminishing reactivity in IR-C, and no activity in CTRL (A). The surface density of KIM-1 immunoreactivity was decreased in the IR-C group compared with the IR-S group and was significantly higher than in the CTRL group (B). Quantification of KIM-1 by

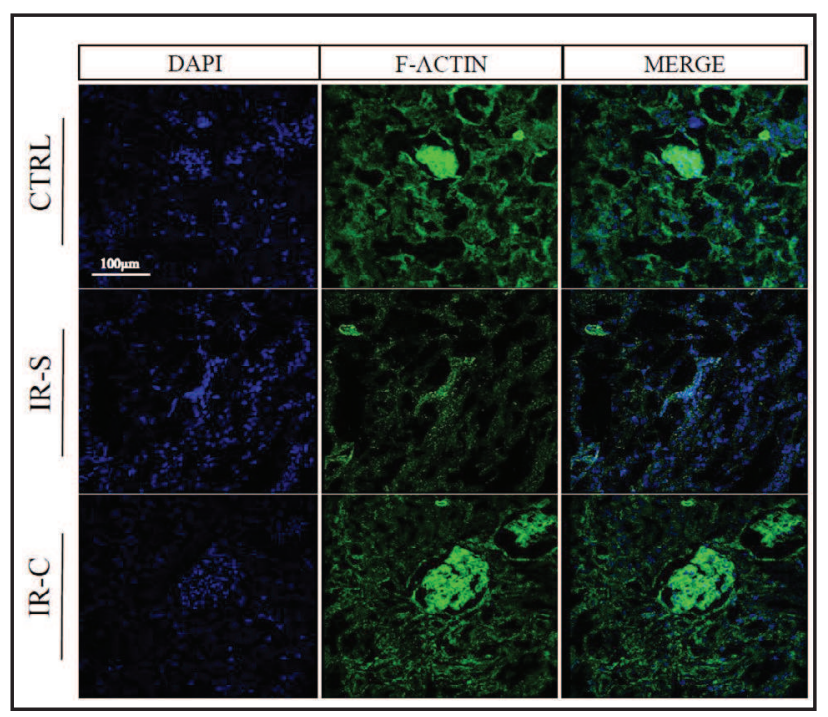
ELISA demonstrated that the IR-S group had the highest level of KIM-1 compared with the other groups $(\mathrm{P}>0.05)$ and that there was decrease in the amount of KIM-1 in the IR-C group compared with the IR-S group (P > 0.05) to levels similar to those in the CTRL group (C).

KIM-1 mRNA levels increase 323.00-fold in IR-S group compared with the CTRL group. The treatment of animals in the IR-C group led to a 0.54-fold decrease in KIM-1 mRNA compared with the animals in the IR-S group, however the reduction was not enough to reach the CTRL levels (Fig. 4D).

\section{Infused BMMCs are recruited to injured kidney hours after infusion and remain for up to} $24 \mathrm{~h}$

One of the characteristics of stem cells is their ability to migrate to the injured tissue as a result of inflammatory signaling [25]. To track the migration of BMMCs and their location in different periods until the end of the experimental protocol, ${ }^{99 \mathrm{~m}}$ Tc-BMMCs in the S-C and IR-C groups were evaluated 2 and $4 \mathrm{~h}$ after infusion. Three-dimensional image reconstruction of the retroperitoneal region depicted the presence of the BMMCs in kidneys and liver in 


\section{Cellular Physiology Cell Physiol Biochem 2017;41:1736-1752 and Biochemistry DOI: 10.1159/000471866 2017 (O 2017 The Author(s). Published by S. Karger AG, Basel}

Ornellas et al.: BMMCs Role in Renal Ischemia and Reperfusion Injury

Table 2. Effects of the Infusion of Bone Marrow-Derived Mononuclear Cells on Renal Function in Renal IR Rats at $24 \mathrm{~h}$ After Renal Reperfusion. GFR, glomerular filtration rate $\left(\mu \mathrm{l} / \mathrm{min} / \mathrm{cm}^{2}\right) ; \mathrm{FE}-\mathrm{Na}^{+}(\%)$, fractional excretion of sodium; FE- $\mathrm{K}^{+}(\%)$, fractional excretion of potassium: CTRL, control; S-S, sham + saline; S-C, BMMC; IR-S, ischemia/reperfusion + saline; IR-C, ischemia/reperfusion + BMMC. Data are shown as means \pm standard error of the mean $( \pm$ SEM), $n=10$ animals per group. *Statistical significance of IR-S compared with all other groups $(P<0.05)$. † Statistical significance of IR-C compared with CTRL, S-S, and S-C $(P<0.05)$

\begin{tabular}{llllll}
\hline & CTRL & S-S & S-C & IR-S & IR-C \\
\hline Urinary flow $(\mu \mathrm{L} / \mathrm{min})$ & $7.05 \pm 0.93$ & $6.82 \pm 1.56$ & $6.02 \pm 1.55$ & $2.80 \pm 0.37^{*}$ & $8.35 \pm 1.91 \dagger$ \\
GFR $\left(\mu \mathrm{L} / \mathrm{min} / \mathrm{cm}^{2}\right)$ & $804.10 \pm 92.90$ & $605.10 \pm 57.82$ & $633.70 \pm 29.31$ & $169.30 \pm 87.32^{*}$ & $556.70 \pm 6.65 \dagger$ \\
FE- $\mathrm{Na}^{+}(\%)$ & $0.25 \pm 0.03$ & $0.27 \pm 0.02$ & $0.24 \pm 0.03$ & $1.08 \pm 0.16^{*}$ & $0.56 \pm 0.02 \dagger$ \\
FE-K+ $(\%)$ & $29.76 \pm 3.63$ & $37.39 \pm 10.53$ & $33.00 \pm 1.41$ & $156.50 \pm 11.59^{*}$ & $115.40 \pm 7.92^{*} \dagger$ \\
\hline
\end{tabular}

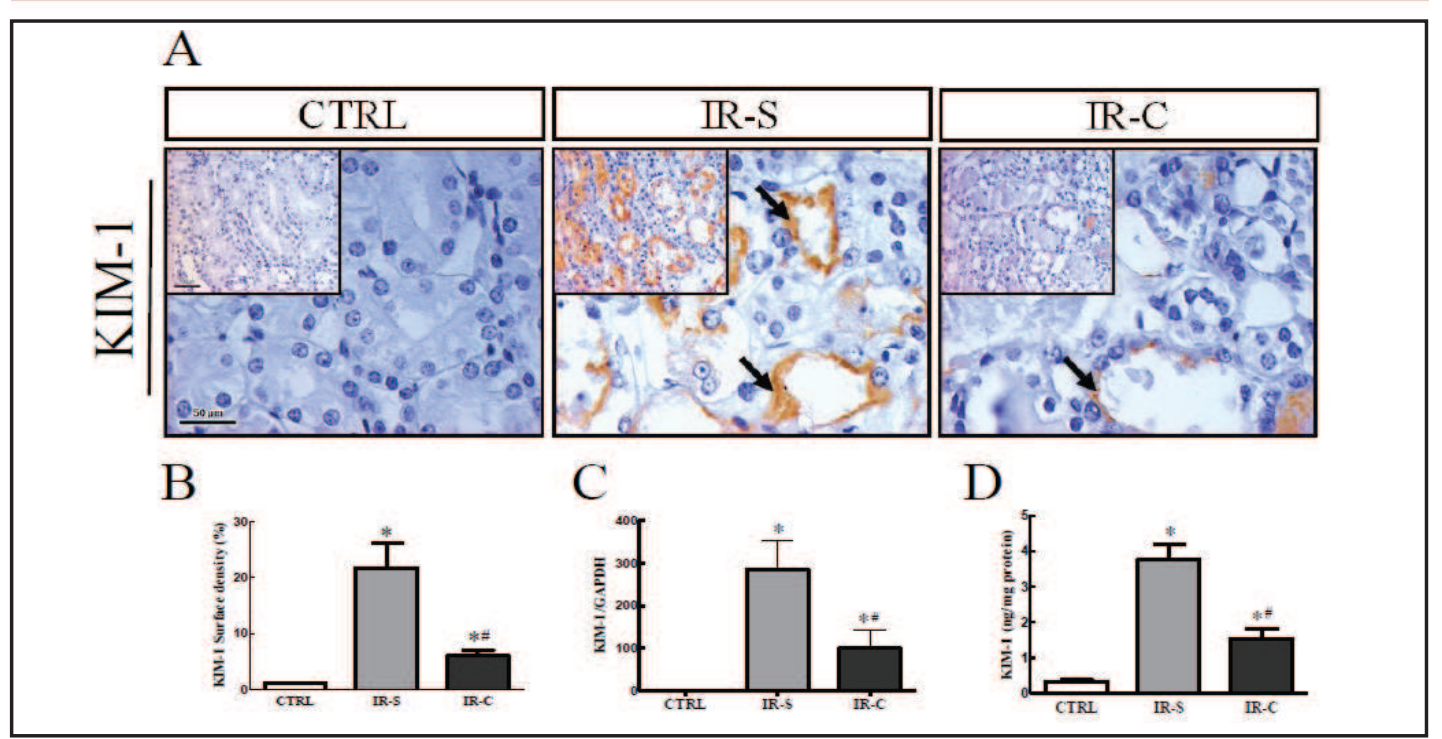

Fig. 4. Representative figure of immunostaining of kidney injury molecule (KIM)-1. (A) Representative photomicrograph of stain per area: KIM-1. CTRL, control; S-S, sham + saline; S-C, BMMC; IR-S, ischemia/reperfusion + saline; IR-C, ischemia/reperfusion + BMMC. (B) Graphic representation of stain per area: KIM-1. (C) mRNA KIM-1 expression by real-time RT-PCR. GAPDH gene was used as internal control. (D) Protein tissue KIM-1 levels by ELISA analysis. Data are expressed as means \pm standard error of the mean $(n=8) . *$ Statistical significance of CTRL $(P<0.05)$. \#Statistical significance of IR-S $(P<0.05)$.

Fig. 5. Tracking of bone marrow-derived mononuclear (BMMC) cells. (A) SPECT/CT 3D reconstruction $2 \mathrm{~h}$ after intravenous injection of ${ }^{99 \mathrm{~m}} \mathrm{Tc}-\mathrm{BMMCs}$ in ischemia/reperfusion (IR-C) animals demonstrating uptake in the liver (L) and both kidneys (K). (B) SPECT/CT coronal views of ${ }^{99 \mathrm{~m}} \mathrm{Tc}-\mathrm{BMMC} 2$ and $4 \mathrm{~h}$ after jugular vein administration in a sham rat (S-C) showing uptake in the liver (L) and spleen (S), and 2 and $4 \mathrm{~h}$ after jugular vein administration in an ische$\mathrm{mic} /$ reperfusion model rat (IR-C) showing uptake in the liver (L) and kidneys (K) $(n=2)$. (C) Localization of cells from GFP animals $(\times 400)$. GFP spleen, positive control; $\mathrm{S}-\mathrm{C}$, sham + BMMC; IR-C, ischemia/ reperfusion + BMMC $(n=4)$.

the IR-C group (Fig. 5A). ${ }^{99 m}$ Tc-BMMCs were mostly found in the spleen in the $\mathrm{S}-\mathrm{C}$ group, whereas the labeled cells in the IR-C group

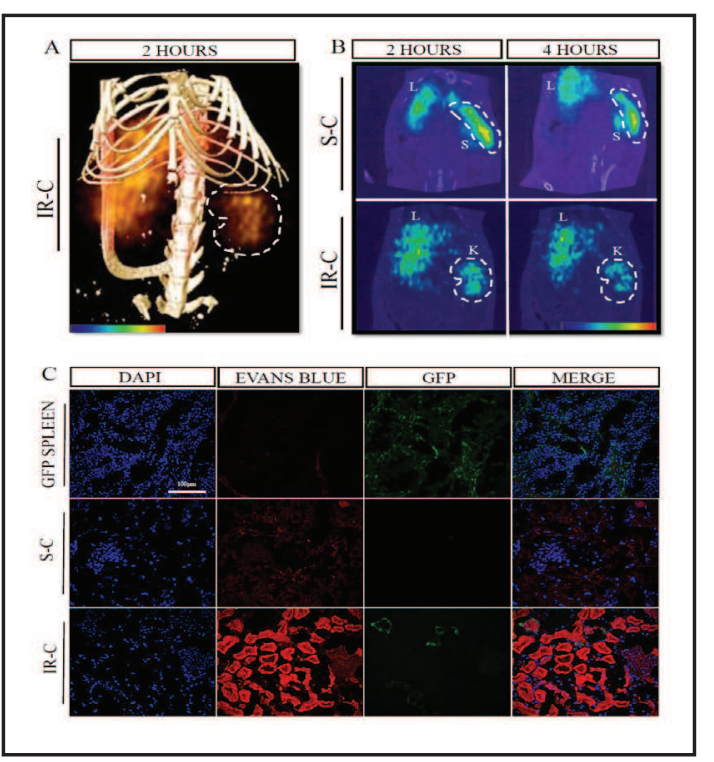




\section{Cellular Physiology Cell Physiol Biochem 2017;41:1736-1752 \begin{tabular}{ll|l} 
and Biochemistry & $\begin{array}{l}\text { DOI: 10.1159/000471866 } \\
\text { Published onIne:1Varch 31, } 2017\end{array}$ & $\begin{array}{l}\text { O 2017 The Author(s). Published by S. Karger AG, Basel } \\
\text { www.karger.com/cpb }\end{array}$ \\
\cline { 2 - 3 }
\end{tabular}

Fig. 6. Graphic representative of levels of molecules correlated to ischemia/reperfusion physiopathology: CTRL, control; IR-S, ischemia/reperfusion + saline; IR-C, ischemia/reperfusion + BMMC. mRNA levels by real-time RT-PCR: toll-like receptor (TLR)2 (A); TLR-4 (B); advanced glycation end products receptor (RAGE) (C); interleukin (IL)-17 (D); IL-18 (E); tumor necrosis factor (TNF- $\alpha$ ) (F); IL-10 GAPDH gene was used as internal control. Protein expression by ELISA: IL-10 (H). (I) Representative photomicrograph of stain per area

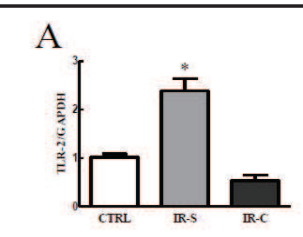

D

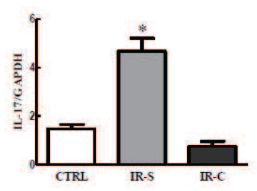

G

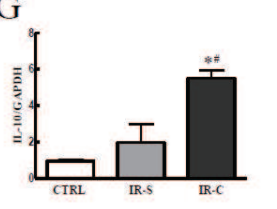

I

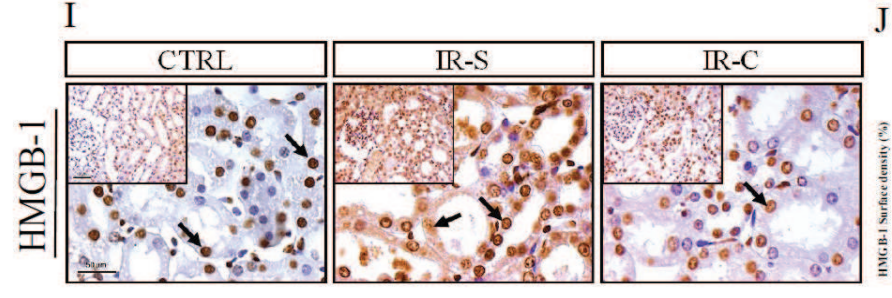

K

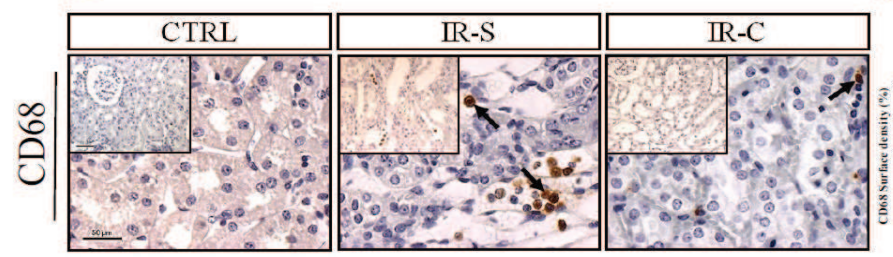

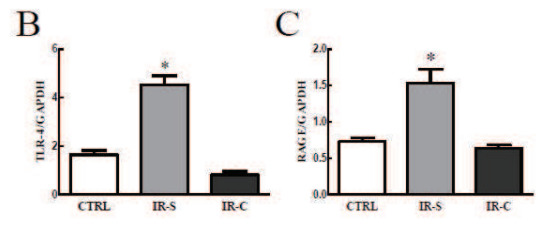

E

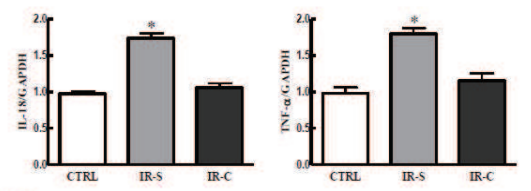

$\mathrm{H}$

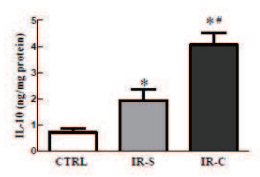

for HMGB-1 ( $\times 200$ and $\times 400)$. (J) Graphic representation of stain per area for HMGB-1. (K) Representative photomicrograph of stain per area for CD68 $(\times 200$ and $\times 400)$. L: Graphic representation of stain per area for CD68. Data are expressed as mean \pm standard error of the mean $(n=8) . *$ Statistical significance of CTRL $(P<0.05)$. \#Statistical significance of IR-S $(P<0.05)$.

were detected mainly in the kidneys (Fig. 5B). Twenty-four hours after IR, GFP+ BMMCs were rarely detected in the tubular compartment (Fig. 5C).

\section{Damage-associated molecular patterns and their receptors are downregulated after BMMC infusion}

The inflammatory process is closely linked to progression of kidney injury induced by IR [26-29]. To evaluate whether the BMMC therapy would be able to interfere with molecules in IR-induced inflammation, we evaluated patterns of inflammatory response after infusion of BMMCs in induced kidney injury in rats. Figure 6A-F shows the mRNA levels of some inflammatory markers: TLR-2, TLR-4, RAGE, IL-17, IL-18, and TNF- $\alpha$. In the IR-S group, the increases in TLR-2, TLR-4, RAGE, IL-17, IL-18, and TNF- $\alpha$ were 1.35-, 1.76-, 1.10-, 2.15-, $0.78-$, and 0.83 -fold, respectively, compared with the CTRL group. The IR-C group showed no significant difference compared with the CTRL group for all mRNAs analyzed.

The cellular inflammatory response of kidneys subjected to IRI was studied by measuring the surface density of CD68 (macrophage), and the resultant tubular damage was depicted by measuring HMGB1. CD68 reactive macrophages were present in the interstitial space and glomeruli of IR groups. HMGB1 immunoreactivity was observed in the cytoplasm of tubule cells 


\section{Cellular Physiology Cell Physiol Biochem 2017;41:1736-1752

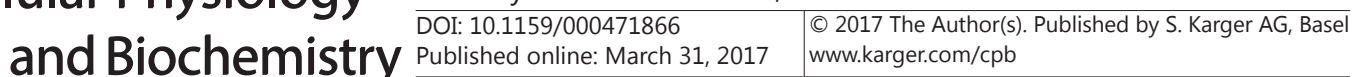

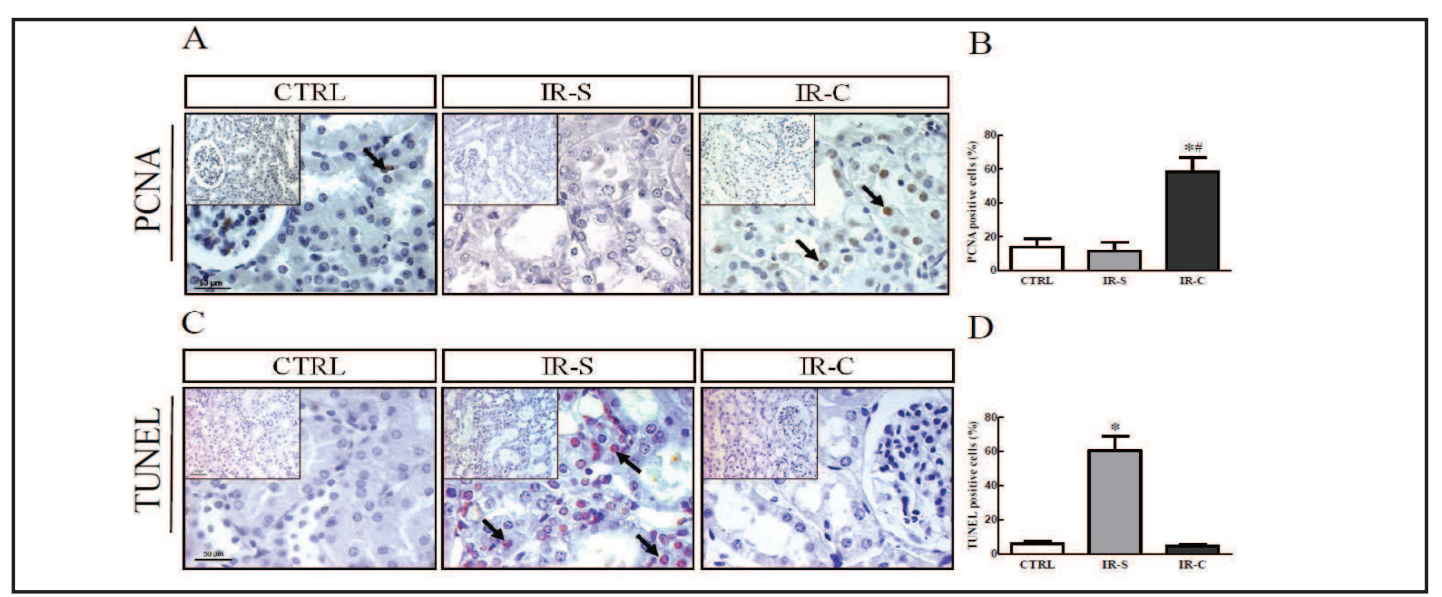

Fig. 7. (A) Representative photomicrograph of PCNA-positive staining ( $\times 200$ and $\times 400)$. (B) Graphic representation of PCNA-positive area. CTRL, control; S-S, sham + saline; S-C, BMMC; IR-S, ischemia/reperfusion + saline; IR-C, ischemia/reperfusion + BMMC. (C) Representative photomicrograph of apoptosis by TUNEL staining $(\times 200$ and $\times 400)$. (D) Graphic representation of positive TUNEL staining per area. All data are expressed as means \pm standard error of the mean $(n=8)$. *Statistical significance of CTRL $(P<0.05)$. \#Statistical significance of IR-S $(P<0.05)$.

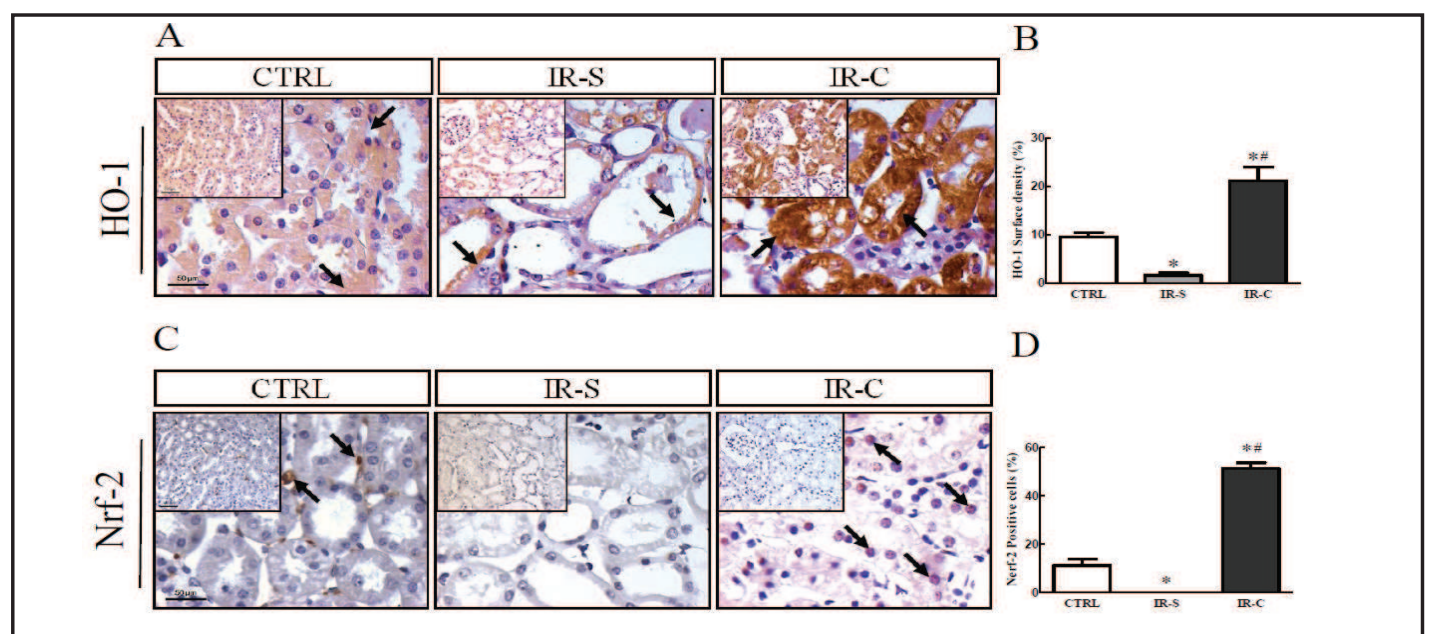

Fig. 8. (A) Representative photomicrograph of HO-1 $(\times 200$ and $\times 400)$. (B) Graphic representation of positive HO-1 staining per area. (C) Representative photomicrograph of Nrf-2-positive staining ( $\times 200$ and $\times 400$ ). (D) Graphic representation of Nrf-2 positive area. CTRL, control; S-S, sham + saline; S-C, BMMC; IR-S, ischemia/reperfusion + saline; IR-C, ischemia/reperfusion + BMMC. All data are expressed as means \pm standard error of the mean $(n=8)$. *Statistical significance of CTRL $(P<0.05)$. \#Statistical significance of IR-S $(P<0.05)$.

and macrophages, and in the tubule cell nuclei. Cytoplasmic HMGB1 significantly increased in the IR-S group and decreased after BMMC infusion (IR-C group). However, HMGB1 nuclear reactivity significantly decreased in both IR groups compared with the CTRL rats, but the difference between the IR groups was not significant (Fig. 6I-J). CD68 surface density significantly increased after IR-S and returned to control values when BMMCs were administered (IR-C group) (Fig. 6K-L). Nevertheless, infusion of BMMCs increased gene and protein expression of the anti-inflammatory cytokine IL-10 compared with the CTRL and IR-S groups (Fig. 6G-H).

BMMCs stimulate proliferation and decrease apoptosis in tubule cells $24 \mathrm{~h}$ after IR

The experiments depicted in Fig. 6 suggest that BMMCs administration could prevent early damage in proximal tubule cells, which can endanger the long-term survival of renal KARGER 


\section{Cellular Physiology Cell Physiol Biochem 2017;41:1736-1752

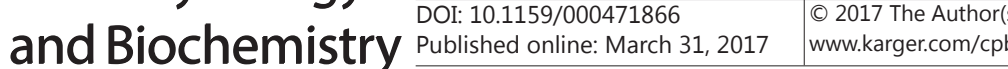 \\ Ornellas et al.: BMMCs Role in Renal Ischemia and Reperfusion Injury}

transplant after IR as well as structural/functional recovery in the case of AKI. Figure 7A and $\mathrm{B}$ shows that BMMCs induced proliferation in the kidney, measured by the percentage of cells that were positive for PCNA, with a 4.15-fold increase in the IR-C group in relation to the IR-S group. Animals in the IR-C group showed no significant difference in the relative levels of mRNA of pro-caspase- 3 compared with animals in the CTRL group, although the IR-S group showed a 4.56-fold increase in this molecule compared with the CTRL group (Fig. 7A). The number of apoptotic cells increased 9.14-fold in IR-S group and decreased to the control value after BMMC infusion (IR-C group) (Fig. 7C-E).

\section{BMMC infusion induces Nrf2 and HO-1 expression after renal IR}

To identify whether the Nrf2/HO-1 signaling pathway is involved in the renoprotective effect of BMMCs, we analyzed ischemic renal tissue using a immunohistochemical technique in each group. Immunohistochemical analysis of renal tissues showed that Nrf-2 was present in tubular cell nuclei, and HO-1 was present in inflammatory cells and renal tubular cells. BMMCs led to a 50.38-fold increase in Nrf2 in the nuclei and 11.44-fold increase of HO-1 in the cytoplasm of tubule cells compared with the IR-S group (Fig. 8A-D).

\section{Discussion}

In this study, we evaluated the therapeutic effect of BMMCs in kidney IR in rats and provide new information on the effect of BMMCs in an AKI model. We induced bilateral IRI in female rats to provoke severe IRI because females have a high tolerance to AKI. Estrogen has a protective role but the mechanism of this protection is not well known [30]. Thus, to achieve tubular injury in females, we conducted experiments using bilateral ischemia for 1 $\mathrm{h}$ followed by reperfusion to induce severe tubular injury caused by impairment of bilateral arterial and venous flow. The tubular histological profile, markers of tubular injury, tubular cell death and proliferation, the inflammatory response, and renal function were analyzed.

Unilateral IR-induced renal injury is a well-known and extensively used model of acute renal injury but, changes seen in this model IR are not the same as in the AKI model. The advantage of using the bilateral IRI model is that the total renal mass is affected, and consequently a measurable increase in serum creatinine and blood urea nitrogen, functional parameters seen in AKI patients, is induced [31]. In addition, the use of this model has provided greater understanding of the underlying pathophysiology, such as vascular and proximal tubule injury, the inflammatory process, the repair mechanisms, and fibrotic evolution. However, little success has been achieved in clinical translation of therapeutic agents found in these animal models.

One of the limiting factors for the translation of this experimental model to humans is that, in humans, AKI is a focal and limited lesion in tubular cells and strongly contrasts with severe damage to renal function. Unfortunately, this phenomenon is not so well represented by most experimental models in rodents, where it is observed as an exacerbated injury. Therefore, the clinical relevance of such models, although highly consistent, is limited, and their distribution pattern of injury may be ambiguous. The proximal and distal tubular ischemic lesions can be observed under diverse clinical conditions, possibly with different therapeutic implications [32].

Here, we demonstrate that in severe IRI in rats, BMMC therapy administered soon after reperfusion improved renal structure and function (urinary flow and GFR) with reversal of increased sodium and potassium wasting close to the values found for control animals, suggesting that this therapy attenuates the tubular epithelial injury (Table 2). One of the signs of the protective effect of BMMCs is reversal of the F-actin profile in tubular cells (Fig. 3) as well as the regulation of the $\mathrm{Na}^{+}$and $\mathrm{K}^{+}$excretion (Table 2). It is well known, after ischemic injury, the normal framework of F-actin in renal proximal tubular epithelial cells is rapidly disrupted [33,34]. Alterations in the actin cytoskeleton impair the epithelial cell architecture, allowing the formation of extracellular vesicles (blebs), dissociation of the cellular junctional complex with subsequent lateral diffusion of membrane lipids, and integral and peripheral membrane proteins with loss of cell polarity $[35,36]$. This disruption is caused primarily by 


\section{Cellular Physiology Cell Physiol Biochem 2017;41:1736-1752 and Biochemistry Published online: March 31, $2017 \quad \begin{aligned} & \text { O 2017 The Authors. } \\ & \text { www.karger.com/cpb }\end{aligned}$ \\ Ornellas et al.: BMMCs Role in Renal Ischemia and Reperfusion Injury}

a decrease in ATP, which, besides affecting the cytoskeletal profile, leads to translocation of basolateral $\mathrm{Na}^{+} / \mathrm{K}^{+} A T P a e^{3,4}$ and a decrease in the carrier levels of $\mathrm{Na}^{+}$and $\mathrm{K}^{+}[37,38]$.

Models of ischemia in rats show that the early morphological alterations are the loss of the renal brush border, pathological alteration present in all proximal tubule segments within hours after IRI [39], followed by cell necrosis, apoptosis, or autophagy, cell detachment, basement membrane denudation, and casts formation in the tubular lumen. In consequence dilatation of tubules occur in addition to interstitial inflammation [40, 41]. The tubular injury score (Fig. 2) showed that the renal morphological changes observed in IR-S group were reversed by the cellular therapy. In addition, cell death analysis by TUNEL showed that tubular cell apoptosis, in addition to cell necrosis, increased in the IR-S animals (Fig. 7C and D), consistent with previous reports [42]. Tubular cell apoptosis decreased in IR-C animals, which suggests that BMMCs could be involved in the preservation of tubular cell metabolism, the caspase activation process, and generation of other mediators of kidney damage caused by IRI.

In order to confirm the extent of tubular injury, we evaluated this through the expression of KIM-1 mRNA and protein in the kidney tissue and KIM-1 immunolocalization. All these assays clearly demonstrated attenuation of tubular injury in the IR-C group compared with the IR-S group (Fig. 4). KIM-1 has been proposed as an early marker for renal damage because this putative epithelial cell-adhesion molecule is upregulated under various conditions in which proximal tubule cells are injured, resulting in their dedifferentiation, and is therefore considered an early sign of damage [43].

IRI is sustained and exacerbated by a robust inflammatory response with activation of the innate and adaptive immune response. Factors that initiate cellular damage and trigger the inflammatory response cascade and renal injury are not completely understood after renal IRI. After cell injury, HMGB1, which is involved in DNA organization and transcription regulation, undergoes nuclear-cytoplasmic translocation. Once released into the circulation, HMGB1 can interact with different receptors (including RAGE, TLR-2, TLR4) on target cells, leading to activation of NADPH oxidase, NF- $\mathrm{KB}$, and immunostimulatory and chemotactic responses $[44,45]$. In this study, we investigated the role of BMMCs in the regulation of the inflammatory response, in particular the pattern recognition receptors such as TLR-2, TLR4, and RAGE, as well as the HMGB1 molecule, which plays a fundamental role in sustaining and amplifying the pro-inflammatory signaling pathways and seems to be vital in the early stages of damage signal propagation in response to IR $[46,47]$. Treatment of human proximal tubular epithelial cells with recombinant human HMGB1 induced alterations in tubular cells consistent with an epithelial mesenchymal transition effect mediated by TGF- $\beta 1$ and in part by RAGE [48]. Moreover, HMGB1 has a strong effect in the attraction and homing of mesangioblasts [49] and bone marrow endothelial progenitors [50]. Other studies have implicated TLR-2 and TLR-4 activation of inflammatory responses in IR. Mice with a genetic deletion for TLR-2 and TLR- 4 are protected from cell changes and increased inflammation when subjected to IRI $[51,52]$. Furthermore, a study with patients who underwent renal transplantation revealed a detrimental role of TLR-2 and TLR-4 signaling, leading to early loss of the graft [52]. Endogenous amplifiers TLR-2 and TLR-4, as well as the HMGB1, are increased in renal transplantation in humans, thus supporting a role for TLR-2 and TLR4 in inflammation in the kidney. Kidneys of patients with a loss-of-function allele for TLR-4 contained lower levels of pro-inflammatory cytokines, in combination with higher functional rates immediately after transplantation graft $[53,54]$. The reduction in HMGB1 in IR-C animals compared with IR-S animals (Fig. 6I and J) contributes to affirmation of a possible role of HMGB1 as a stimulator of the pro-inflammatory pathway as well as the role of BMMC therapy as an inhibitor of exacerbation of the inflammatory process. As previously described, HMGB1 binds with high affinity to RAGE [50]. Hence, we observed decreased mRNA expression levels of RAGE in the IR-C group compared with the IR-S group (Fig. 6D). These results reinforce the modulatory role of BMMCs in the inflammatory response in a renal IRI model.

Among the responsive molecules involved in the inflammatory process after IRI, cellular therapy (in the IR-S group) decreased the augmented IL-18 and TNF- $\alpha$ mRNA (found in the IR-C 


\section{Cellular Physiology Cell Physiol Biochem 2017;41:1736-1752

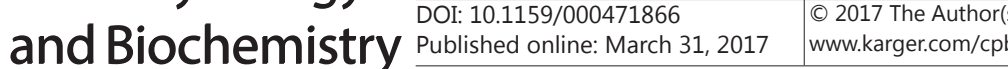 \\ Ornellas et al.: BMMCs Role in Renal Ischemia and Reperfusion Injury}

group) to levels similar to control animals (Fig. 6E and F). These results are in agreement with data reported by Wu et al. [55] where IL-18 deficient mice subjected to renal IR showed better renal function compared with normal animals with the same injury. The improved function was associated with a reduced amount of tubular damage and decreased expression of pro-inflammatory molecules, including IL-18. IL-18 is well known to contribute to the worsening of renal injury induced by IRI, whereas TNF- $\alpha$ is an important mediator in the causation and perpetuation of previously observed kidney injury [56-58].

Another key regulator of the inflammatory response system, IL-17, bridges innate immunity to adaptive immunity [59]. Increased IL-17 levels are seen in many inflammatory diseases such as sepsis, rheumatoid arthritis, pneumonia, lupus erythematosus, graft rejection, among others [60-62], suggesting a potential role of this cytokine in the initiation and/or the maintenance of inflammatory responses. In the present study, we show that the IR-S groups have increased IL-17 mRNA levels. On the other hand, the IR-C group had attenuation of IL-17 mRNA levels, similar to the values for the CTRL group (Fig. 6C).

In contrast, when we evaluated IL-10 expression, an anti-inflammatory cytokine, we found a significant increase in IR-C animals (Fig. 6G-H). As suggested before by Xue et al., there is a balance in the inflammatory process by linking IL-17 and IL-10 in the IR animal model [61]. Our results suggest the direct action of cell therapy in this inflammatory balance by inhibiting IL-17 and stimulating IL-10, negatively regulating the inflammatory cytokine levels in kidney tissue.

It is known that in IRI, reperfusion causes more damage to the tissue than the ischemic phase [63]. One of the mechanisms involved in reperfusion-induced injury is the production of ROS $[64,65]$. ROS are constantly being produced in cells but the presence of antioxidant enzymes/systems in cells efficiently counterbalance these molecules [66]. Therefore, we investigated the role of the nuclear factor, erythroid 2-related factor 2 (Nrf2)/kelch-like ECHassociated protein 1 (keap 1)/heme oxidase-1 (HO-1) system, a major mechanism in the cellular defense against oxidative or electrophilic stress. We showed increased expression of Nrf2 and HO-1 protein in renal tissue in rats subjected to IRI and treated with BMMCs (Fig. 8). Nrf2 regulates the basal and inducible expression of numerous antioxidant stress genes and has cell protective and proliferative effects $[67,68]$. Nrf2 also coordinates the induction of genes encoding antioxidant enzymes. One of them is HO-1, which acts as an antioxidant because it contributes to the withdrawal of excessive heme molecules, a prooxidant agent [69]. Moreover by inducing an anti-inflammatory environment, $\mathrm{HO}-1$ was seen to have a protective role in IRI, and macrophages that overexpress HO-1 have an anti-inflammatory phenotype [59, 70].

Furthermore, attenuation of the IRI seen in the IR-C animals is likely due to the regenerative effects of BMMC administration whereby dead tubular cells are rapidly replaced by new ones. The proliferative burst was depicted by the increase in the PCNA index of tubular cells of IR-C animals (Fig. 7A-B) compared with animals in the control group. On the other hand, the decrease in tubular cell apoptosis, also found here in the IR-C group, corroborates the cytoprotective effect of cell therapy; diminution of the apoptotic levels could have reestablished equilibrium in the kinetics of the tubular compartment. This improvement induced by BMMCs has been already been shown in several acute and chronic models of disease after diverse kinds of cell therapy $[13-15,71]$ and seems to be due to the production of pro-survival growth factors [72-74].

In the present study, we used the BMMCs because this cell population seems to increase the ability to self-repair the kidney $[13,75]$. We observed that cells administered intravenously migrated mainly to the kidneys in groups subjected to IRI, albeit in a small amount, suggesting that injured kidney can secrete chemoattraction factors for recruitment of BMMCs, as shown in other studies related to cytokines secreted by the injured microenvironment, such as SDF1 or TGF $\beta 1[76,77]$. Tracking of injected BMMCs labeled with technetium was only possible during the first hours after administration due to the short half-life of Tc [20]. Therefore, we transplanted GFP+ BMMCs and localized them beyond $24 \mathrm{~h}$. Only a small amount of GFP+ BMMCs was observed in the kidney (Fig. 5). Xing et al. [78] showed that MSC infusion promotes kidney repair in a variety of ways. They demonstrate that MSCs can secrete high levels of growth factors, such as hepatocyte growth factor, insulin-like growth factor-1, and vascular endothelial growth factor. The infusion of conditioned medium from these 


\section{Cellular Physiology Cell Physiol Biochem 2017;41:1736-1752 \begin{tabular}{l|l|l}
\hline DOI: 10.1159/000471866 & $\begin{array}{l}\text { @ } 2017 \text { The Author(s). Published by S. Karger AG, Basel } \\
\text { www.karger.com/cpb }\end{array}$ \\
\hline
\end{tabular} Ornellas et al.: BMMCs Role in Renal Ischemia and Reperfusion Injury}

cells in the IRI model results in a nonsignificant improvement, indicating that MSCs play a role in kidney repair through paracrine rather than endocrine mechanisms. Our results demonstrate a significant improvement in the IR-C group in the IR-S. However, the amount of cells present in the kidney interstitial tissue after $24 \mathrm{~h}$ was low, reinforcing the hypothesis of a paracrine mechanism of action.

The self-regeneration of renal tubule cells after toxic injury has been described as a natural process due to the presence of resident intrarenal tubular cells [40]. Humphreys et al. [7] reported that, after IR injury, proliferation of renal epithelial cells began after $48 \mathrm{~h}$. Our study showed that there was an increase in cell proliferation in tubular cells $24 \mathrm{~h}$ after cell therapy, suggesting acceleration of the repopulation process. In addition, BMMCs had a protective role for morphological changes in kidney tissue caused by IRI, as indicated by Chen et al. [79] when they used endothelial progenitor cells derived from bone marrow in a model of renal IR. Their results show that endothelial progenitors favored an increase in the microvasculature, which is associated with improvement in renal function.

In conclusion, BMMC therapy in animals with IR led to improvement in renal function and structure, probably caused by increased antioxidant systems, inhibition of inflammation, and with a cytoprotective effect due to decreased tubular cell death and acceleration of tubular cell proliferation. Therefore, the benefits induced by BMMCs in IRI hold substantial promise for the development of new interventions after kidney transplantation to decrease the deleterious consequences of severe AKI.

\section{Acknowledgments}

The authors would like to express their gratitude to Mr Maicon Calixto and Mrs Karina Gomes for animal care and technical support. This study was supported by Centers of Excellence Program (PRONEX-FAPERJ), Brazilian Council for Scientific and Technological Development (MCT/CNPq), Carlos Chagas Filho Rio de Janeiro State Research Supporting Foundation (FAPERJ), and Coordination for the Improvement of Higher Level Personnel (CAPES).

\section{Disclosure Statement}

None of the authors had any conflict of interest.

\section{References}

1 Santos WJ, Zanetta DM, Pires AC, Lobo SM, Lima EQ, Burdmann EA: Patients with ischaemic, mixed and nephrotoxic acute tubular necrosis in the intensive care unit - a homogeneous population? Crit Care 2006;10:R68.

2 Basile DP, Bonventre J V, Mehta R, Nangaku M, Unwin R, Rosner MH, Kellum JA, Ronco C; ADQI XIII Work Group: Progression after AKI: Understanding Maladaptive Repair Processes to Predict and Identify Therapeutic Treatments. J Am Soc Nephrol 2015;27:687-697.

-3 Gottlieb RA: Cell Death Pathways in Acute Ischemia/Reperfusion Injury. J Cardiovasc Pharmacol Ther 2011;16:233-238.

4 Saïd-Sadier N, Ojcius DM: Alarmins, inflammasomes and immunity. Biomed J 2012;35:437-449.

-5 Coca SG, Yusuf B, Shlipak MG, Garg AX, Parikh CR: Long-term Risk of Mortality and Other Adverse Outcomes After Acute Kidney Injury: A Systematic Review and Meta-analysis. Am J Kidney Dis 2009;53:961-973.

-6 Bonventre J V: Recent Advances in the Pathophysiology of Ischemic Acute Renal Failure. J Am Soc Nephrol 2003;14:2199-2210.

7 Humphreys BD, Valerius MT, Kobayashi A, Mugford JW, Soeung S, Duffield JS, McMahon AP, Bonventre JV: Intrinsic Epithelial Cells Repair the Kidney after Injury. Cell Stem Cell 2008;2:284-291.

8 Duffield JS, Park KM, Hsiao L-L, Kelley VR, Scadden DT, Ichimura T, Bonventre JV: Restoration of tubular epithelial cells during repair of the postischemic kidney occurs independently of bone marrow-derived stem cells. J Clin Invest 2005;115:1743-1755.

-9 Malek M, Nematbakhsh M: Renal ischemia/reperfusion injury; from pathophysiology to treatment. J Ren Inj Prev 2015;4:20-27. 


\section{Cellular Physiology Cell Physiol Biochem 2017;41:1736-1752 \begin{tabular}{l|l} 
DOI: 10.1159/000471866 & $\begin{array}{l}\text { ○ 2017 The Author(s). Published by S. Karger AG, Basel } \\
\text { www.karger.com/cpb }\end{array}$ \\
\hline
\end{tabular}}

Ornellas et al.: BMMCs Role in Renal Ischemia and Reperfusion Injury

10 Tögel FE, Westenfelder C: Kidney Protection and Regeneration Following Acute Injury: Progress Through Stem Cell Therapy. Am J Kidney Dis 2012;60:1012-1022.

-11 Reinders MEJ, de Fijter JW, Roelofs H, Bajema IM, de Vries DK, Schaapherder AF, Claas FH, van Miert PP, Roelen DL, van Kooten C, Fibbe WE, Rabelink: Autologous bone marrow-derived mesenchymal stromal cells for the treatment of allograft rejection after renal transplantation: results of a phase I study. Stem Cells Transl Med 2013;2:107-111.

- 12 Ferrari G, Cusella-De Angelis G, Coletta M, Paolucci E, Stornaiuolo A, Cossu G, Mavilio F: Muscle regeneration by bone marrow-derived myogenic progenitors. Science 1998;279:1528-1530.

-13 Barreira AL, Takiya CM, Castiglione RC, Maron-Gutierrez T, Barbosa CML, Ornellas DS, Verdoorn KS, Pascarelli BM, Borojevic R, Einicker-Lamas M, Leite M Jr, Morales MM, Vieyra A: Bone marrow mononuclear cells attenuate interstitial fibrosis and stimulate the repair of tubular epithelial cells after unilateral ureteral obstruction. Cell Physiol Biochem 2009;24:585-594.

-14 Ornellas DS, Maron-Gutierrez T, Ornellas FM, Cruz FF, Oliveira GP, Lucas IH, Fujisakia L, Oliveira MG, Teodoroc WR, Capelozzic VL, Pelosi P, Morales MM, Rocco PRM: Early and late effects of bone marrowderived mononuclear cell therapy on lung and distal organs in experimental sepsis. Respir Physiol Neurobiol 2011;178:304-314.

-15 Castiglione RC, Maron-Gutierrez T, Barbosa CML, Ornellas FM, Barreira AL, Dibarros CB a, Vasconcelosdos-Santos A, Paredes BD, Pascarelli BM, Diaz BL, Rossi-Bergmann B, Takiya CM, Rocco PR, Souza-Menezes J, Morales MM: Bone marrow-derived mononuclear cells promote improvement in glomerular function in rats with early diabetic nephropathy. Cell Physiol Biochem 2013;32:699-718.

- 16 Perin EC, Dohmann HFR, Borojevic R, Silva SA, Sousa ALS, Mesquita CT, Mesquita CT, Rossi MI, Carvalho AC, Dutra HS, Dohmann HJ, Silva GV, Belém L, Vivacqua R, Rangel FO, Esporcatte R, Geng YJ, Vaughn WK, Assad JA, Mesquita ET, Willerson JT: Transendocardial, autologous bone marrow cell transplantation for severe, chronic ischemic heart failure. Circulation 2003;107:2294-2302.

17 Yang B, Parsha K, Schaar K, Xi X, Aronowski J, Savitz SI: Various Cell Populations Within the Mononuclear Fraction of Bone Marrow Contribute to the Beneficial Effects of Autologous Bone Marrow Cell Therapy in a Rodent Stroke Model. Transl Stroke Res DOI:10.1007/s12975-016-0462-x.

18 Song F, Tang J, Geng R, Hu H, Zhu C, Cui W, Fan W: Comparison of the efficacy of bone marrow mononuclear cells and bone mesenchymal stem cells in the treatment of osteoarthritis in a sheep model. Int J Clin Exp Pathol 2014;7:1415-1426.

19 van der Spoel TIG, Gathier WA, Koudstaal S, van Slochteren F, of Lorkeers SJ, Sluijter JPG, Hoefer IE, Steendijk P, Cramer MJ, Doevendans PA, van Belle E, Chamuleau SA: Autologous Mesenchymal Stem Cells Show More Benefit on Systolic Function Compared to Bone Marrow Mononuclear Cells in a Porcine Model of Chronic Myocardial Infarction. J Cardiovasc Transl Res 2015;8:393-403.

-20 Suhett GD, de Souza SAL, Carvalho AB, de Pinho Rachid R, da Cunha-E-Silva NL, de Carvalho ACC, da Fonseca LM, dos Santos Goldenberg RC, Gutfilen B: 99m-Technetium binding site in bone marrow mononuclear cells. Stem Cell Res Ther 2015;6:115.

-21 Hammond JB, Kruger NJ: The bradford method for protein quantitation. Methods Mol Biol 1988;3:25-32.

-22 Jung M, Sola A, Hughes J, Kluth DC, Vinuesa E, Viñas JL, Pérez-Ladaga A, Hotter G: Infusion of IL-10expressing cells protects against renal ischemia through induction of lipocalin-2. Kidney Int 2012;81:969982.

-23 Antunes N, Martinusso C a, Takiya CM, da Silva a JR, de Ornellas JFR, Elias PR, Leite M Jr, Cardoso LR: Fructose-1,6 diphosphate as a protective agent for experimental ischemic acute renal failure. Kidney Int 2006;69:68-72.

-24 Hu M-C, Moe OW: Klotho as a potential biomarker and therapy for acute kidney injury. Nat Rev Nephrol 2012;8:423-429.

-25 Xinaris C, Morigi M, Benedetti V, Imberti B, Fabricio AS, Squarcina E, Benigni A, Gagliardini E, Remuzzi G: A novel strategy to enhance mesenchymal stem cell migration capacity and promote tissue repair in an injury specific fashion. Cell Transplant 2013;22:423-436.

26 Shen Y, Wang Y, Li D, Wang C, Xu B, Dong G, Huang H, Jing H: Recombinant Human Erythropoietin Pretreatment Attenuates Heart Ischemia-Reperfusion Injury in Rats by Suppressing the Systemic Inflammatory Response. Transplant Proc 2010;42:1595-1597.

-27 Schmidt E, Tuder R: Role of apoptosis in amplifying inflammatory responses in lung diseases. J Cell Death 2010;2010:41-53.

28 Akcay A, Nguyen Q, Edelstein CL: Mediators of inflammation in acute kidney injury. Mediators Inflamm DOI:10.1155/2009/137072.

-29 Harris HE, Andersson U, Pisetsky DS: HMGB1: a multifunctional alarmin driving autoimmune and inflammatory disease. Nat Rev Rheumatol 2012;8:195-202. 


\section{Cellular Physiology Cell Physiol Biochem 2017;41:1736-1752 \begin{tabular}{l|l|l}
\hline DOI: 10.1159/000471866 & () 2017 The Author(s). Published by S. Karger AG, Basel
\end{tabular}

-30 Noel S, Desai NM, Hamad ARA, Rabb H: Sex and the single transplanted kidney. J Clin Invest 2016;126:1643-1645.

-31 Holderied A, Anders H-J: Animal models of kidney inflammation in translational medicine. Drug Discov Today Dis Model 2014;11:19-27.

-32 Heyman SN, Rosenberger C, Rosen S: Experimental ischemia-reperfusion: biases and myths—the proximal vs. distal hypoxic tubular injury debate revisited. Kidney Int 2010;77:9-16.

33 Kellerman PS, Clark R, Hoilien C, Linas SL, Molitoris B: Role of microfilaments in maintenance of proximal tubule structural and functional integrity. Am J Physiol 1990;259:F279-F285.

-34 Ashworth SL, Molitoris BA: Pathophysiology and functional significance of apical membrane disruption during ischemia. Curr Opin Nephrol Hypertens 1999;8:449-458.

-35 Sheridan AM, Bonventre JV: Cell biology and molecular mechanisms of injury in ischemic acute renal failure. Curr Opin Nephrol Hypertens 2000;9:427-434.

-36 Kosieradzki M, Rowiński W: Ischemia/Reperfusion Injury in Kidney Transplantation: Mechanisms and Prevention. Transplant Proc 2008;40:3279-3288.

- 37 Molitoris BA, Geerdes A, McIntosh JR: Dissociation and redistribution of $\mathrm{Na}+\mathrm{K}(+)$-ATPase from its surface membrane actin cytoskeletal complex during cellular ATP depletion. J Clin Invest 1991;88:462-469.

- 38 Kwon TH, Frøkiaer J, Han JS, Knepper M a, Nielsen S: Decreased abundance of major Na(+) transporters in kidneys of rats with ischemia-induced acute renal failure. Am J Physiol Renal Physiol 2000;278:F925-939.

-39 Venkatachalam MA, Bernard DB, Donohoe JF, Levinsky NG: Ischemic damage and repair in the rat proximal tubule: differences among the S1, S2, and S3 segments. Kidney Int 1978;14:31-49.

-40 Sharfuddin AA, Molitoris BA: Pathophysiology of ischemic acute kidney injury. Nat Rev Nephrol 2011;7:189-200.

41 Guan X, Qian Y, Shen Y, Zhang L, Du Y, Dai H, Qian J, Yan Y: Autophagy protects renal tubular cells against ischemia / reperfusion injury in a time-dependent manner. Cell Physiol Biochem 2015;36:285-298.

-42 Hassoun HT, Lie ML, Grigoryev DN, Liu M, Tuder RM, Rabb H: Kidney ischemia-reperfusion injury induces caspase-dependent pulmonary apoptosis. Am J Physiol Renal Physiol 2009;297:F125-137.

-43 Ichimura T, Hung CC, Yang SA, Stevens JL, Bonventre JV: Kidney injury molecule-1: a tissue and urinary biomarker for nephrotoxicant-induced renal injury. Am J Physiol Renal Physiol 2004;286:F552-F563.

-44 Park JS, Gamboni-Robertson F, He Q Svetkauskaite D, Kim J-Y, Strassheim D, Sohn JW, Yamada S, Maruyama I, Banerjee A, Ishizaka A, Abraham E: High mobility group box 1 protein interacts with multiple Toll-like receptors. Am J Physiol Cell Physiol 2006;290:C917-924.

45 Yanai H, Ban T, Wang Z, Choi MK, Kawamura T, Negishi H, Nakasato M, Lu Y, Hangai S, Koshiba R, Savitsky D, Ronfani L, Akira S, Bianchi ME, Honda K, Tamura T, Kodama T, Taniguchi T: HMGB proteins function as universal sentinels for nucleic-acid-mediated innate immune responses. Nature 2009;462:99-103.

-46 Yamamoto M, Takeda K: Current Views of Toll-Like Receptor Signaling Pathways. Gastroenterol Res Pract DOI:10.1155/2010/240365.

47 Rabadi MM, Ghaly T, Goligorksy MS, Ratliff BB: HMGB1 in renal ischemic injury. Am J Physiol Renal Physiol 2012;303:F873-885.

48 Lynch J, Nolan S, Slattery C, Feighery R, Ryan MP, McMorrow T: High-mobility group box protein 1: A novel mediator of inflammatory-induced renal epithelial-mesenchymal transition. Am J Nephrol 2010;32:590602.

49 Palumbo R, Bianchi ME: High mobility group box 1 protein, a cue for stem cell recruitment. Biochem Pharmacol 2004;68:1165-1170.

-50 Chavakis E, Hain A, Vinci M, Carmona G, Bianchi ME, Vajkoczy P, Zeiher AM, Chavakis T, Dimmeler S: High-mobility group box 1 activates integrin-dependent homing of endothelial progenitor cells. Circ Res 2007;100:204-212.

-51 Farrar CA, Keogh B, McCormack W, O’Shaughnessy A, Parker A, Reilly M, Sacks SH: Inhibition of TLR2 promotes graft function in a murine model of renal transplant ischemia-reperfusion injury. FASEB J 2012;26:799-807.

-52 Zhao H, Perez JS, Lu K, George AJT, Ma D: Role of Toll-like receptor-4 in renal graft ischemia-reperfusion injury. Am J Physiol Renal Physiol 2014;306:F801-811.

-53 Leemans JC, Stokman G, Claessen N, Rouschop KM, Teske GJD, Kirschning CJ, Akira S, van der Poll T, Weening JJ, Florquin S: Renal-associated TLR2 mediates ischemia/reperfusion injury in the kidney. J Clin Invest 2005;115:2894-2903.

54 Takeda K: Toll-like receptors in innate immunity. Int Immunol 2004;17:1-14.

- 55 Wu H, Craft ML, Wang P, Wyburn KR, Chen G, Ma J, Hambly B, Chadban SJ.: IL-18 contributes to renal damage after ischemia-reperfusion. J Am Soc Nephrol 2008;19:2331-2341.

-56 Burne MJ, Elghandour A, Haq M, Saba SR, Norman J, Condon T, Bennett F, Rabb H: IL-1 and TNF independent pathways mediate ICAM-1/VCAM-1 up-regulation in ischemia reperfusion injury. J Leukoc 


\section{Cellular Physiology Cell Physiol Biochem 2017;41:1736-1752 \begin{tabular}{c|l|l}
\cline { 2 - 3 } DOI: 10.1159/000471866 & $\begin{array}{l}\text { ( ) } 2017 \text { The Author(s). Published by S. Karger AG, Basel } \\
\text { www.karger.com/cpb }\end{array}$
\end{tabular}}

Ornellas et al.: BMMCs Role in Renal Ischemia and Reperfusion Injury

Biol 2001;20:192-198.

-57 Misseri R, Meldrum DR, Dinarello CA, Dagher P, Hile KL, Rink RC, Meldrum KK: TNF-alpha mediates obstruction-induced renal tubular cell apoptosis and proapoptotic signaling. Am J Physiol Renal Physiol 2005;288:F406-411.

-58 Wu H, Huang T, Ying L, Han C, Li D, Xu Y, Zhang M, Mou S, Dong Z: MiR-155 is Involved in Renal IschemiaReperfusion Injury via Direct Targeting of FoxO3a and Regulating Renal Tubular Cell Pyroptosis. Cell Physiol Biochem 2016;40:1692-1705.

-59 Ferenbach D a, Ramdas V, Spencer N, Marson L, Anegon I, Hughes J, Kluth DC: Macrophages expressing heme oxygenase-1 improve renal function in ischemia/reperfusion injury. Mol Ther 2010;18:1706-1713.

60 Bettelli E, Oukka M, Kuchroo VK: T H -17 cells in the circle of immunity and autoimmunity 2007;8:345350.

61 Xue L, Xie K, Han X, Yang Z, Qiu J, Zhao Z, Bao T: Detrimental functions of IL-17A in renal ischemiareperfusion injury in mice. J Surg Res 2011;171:266-274.

62 Pisitkun P, Ha H, Wang H, Claudio E, Tivy C: Interleukin-17 cytokines are critical in development of fatal lupus glomerulonephritis. Immunity 2012;37:1104-1115.

63 Gulec B: Ischemia Reperfusion Injury in Kidney Transplantation; in Trzcinska M (ed): Kidney Transplantation - New Perspectives DOI:10.5772/18289.

64 Li C, Jackson RM: Reactive Species mechanims of cellular hypoxia reoxygenation injury. AJP Cell Physiol 2002; 282:227-241.

65 Simone S, Rascio F, Castellano G, Divella C, Chieti A, Ditonno P, Battaglia M, Crovace A, Staffieri F, Oortwijn B, Stallone G, Gesualdo L, Pertosa G, Grandaliano G: Complement-dependent NADPH oxidase enzyme activation in renal ischemia/reperfusion injury. Free Radic Biol Med 2014;74:263-273.

66 Nilakantan V, Hilton G, Maenpaa C, Van Why SK, Pieper GM, Johnson CP, Shames BD: Favorable balance of anti-oxidant/pro-oxidant systems and ablated oxidative stress in Brown Norway rats in renal ischemiareperfusion injury. Mol Cell Biochem 2007;304:1-11.

67 Motohashi H, Yamamoto M: Nrf2-Keap1 defines a physiologically important stress response mechanism. Trends Mol Med 2004;10:549-557.

68 Kim HJ, Vaziri ND: Contribution of impaired Nrf2-Keap1 pathway to oxidative stress and inflammation in chronic renal failure. Am J Physiol Renal Physiol 2010;298:F662-671.

69 Ryter SW, Tyrrell RM: The heme synthesis and degradation pathways: role in oxidant sensitivity. Free Radic Biol Med 2000;28:289-309.

-70 Ollinger R, Kogler P, Biebl M, Sieb M, Sucher R, Bosmuller C, Troppmair J, Mark W, Weiss H, Margreiter R: Protein levels of heme oxygenase- 1 during reperfusion in human kidney transplants with delayed graft function. Clin Transplant 2008;22:418-423.

-71 Araújo IM, Abreu SC, Maron-Gutierrez T, Cruz F, Fujisaki L, Carreira H, Ornellas F, Ornellas D, Vieira-deAbreu A, Castro-Faria-Neto HC, Muxfeldt Ab'Saber A, Teodoro WR, Diaz BL, Peres Dacosta C, Capelozzi VL, Pelosi P, Morales MM, Rocco PR: Bone marrow-derived mononuclear cell therapy in experimental pulmonary and extrapulmonary acute lung injury. Crit Care Med 2010;38:1733-1741.

-72 Iwase T, Nagaya N, Fujii T, Itoh T, Murakami S, Matsumoto T, Kangawa K, Kitamura S: Comparison of angiogenic potency between mesenchymal stem cells and mononuclear cells in a rat model of hindlimb ischemia. Cardiovasc Res 2005;66:543-551.

73 Imberti B, Morigi M, Tomasoni S, Rota C, Corna D, Longaretti L, Rottoli D, Valsecchi F, Benigni A, Wang J, Abbate M, Zoja C, Remuzzi G: Insulin-like growth factor-1 sustains stem cell mediated renal repair. J Am Soc Nephrol 2007;18:2921-2928.

74 Tögel F, Cohen A, Zhang P, Yang Y, Hu Z, Westenfelder C: Autologous and allogeneic marrow stromal cells are safe and effective for the treatment of acute kidney injury. Stem Cells Dev 2009;18:475-485.

75 Semedo P, Donizetti-Oliveira C, Burgos-Silva M, Cenedeze MA, Avancini Costa Malheiros DM, Pacheco-Silva A, Câmara NO: Bone marrow mononuclear cells attenuate fibrosis development after severe acute kidney injury. Lab Invest 2010;90:685-695.

76 Si X, Liu X, Li J, Wu X: Transforming growth factor- $\beta 1$ promotes homing of bone marrow mesenchymal stem cells in renal ischemia-reperfusion injury 2015;8:12368-12378.

-77 Tögel F, Isaac J, Hu Z, Weiss K, Westenfelder C: Renal SDF-1 signals mobilization and homing of CXCR4positive cells to the kidney after ischemic injury. Kidney Int 2005;67:1772-1784.

78 Xing L, Cui R, Peng L, Ma J, Chen X, Xie RJ, Li B: Mesenchymal stem cells, not conditioned medium, contribute to kidney repair after ischemia-reperfusion injury. Stem Cell Res Ther 2014;5:101.

-79 Chen B, Bo CJ, Jia R-P, Liu H, Wu R, Wu J, Ge YZ, Teng GJ: The renoprotective effect of bone marrow-derived endothelial progenitor cell transplantation on acute ischemia-reperfusion injury in rats. Transplant Proc 2013; 45:2034-2039. 